\title{
sciendo
}

\section{CARCASS CHARACTERISTICS AND MEAT QUALITY OF CONVENTIONALLY AND ORGANICALLY REARED SUCKLING DAIRY GOAT KIDS OF THE PAYOYA BREED*}

\author{
José Luis Guzmán ${ }^{1}$, Francisco de la Vega ${ }^{2}$, Luis Ángel Zarazaga ${ }^{1}$, Anastasio Argüello ${ }^{3}$, \\ Manuel Delgado-Pertíñez ${ }^{2}$
}

\begin{abstract}
${ }^{1}$ Departamento de Ciencias Agroforestales, Escuela Técnica Superior de Ingeniería, Universidad de Huelva, Campus de Excelencia Internacional Agroalimentario, ceiA3, Campus de la Rábida, 21819 Palos de la Frontera, Huelva, Spain

${ }^{2}$ Departamento de Ciencias Agroforestales, Escuela Técnica Superior de Ingeniería Agronómica, Universidad de Sevilla, Ctra. Utrera km 1, 41013 Sevilla, Spain

${ }^{3}$ Grupo de Producción y Biotecnología Animal, Instituto Universitario de Sanidad Animal y Seguridad Alimentaria, Universidad de Las Palmas de Gran Canaria, Transmontaña s/n, 35413 Arucas, Spain •Corresponding author: Tel.: +34954486449, Fax:+34954486436, E-mail: pertinez@us.es
\end{abstract}

\begin{abstract}
The viability of conventional goat farms, such as the native Payoya dairy goat, could be improved by switching to organic production, but product quality needs to be ensured. The present work assesses the carcass and meat quality of Payoya kids raised under conventional and organic grazing-based systems. Twenty-four kids (12 males, 12 females) were selected from each system $(n=48)$. The slaughter live weight $(8.52 \mathrm{vs} .8 .28 \mathrm{~kg})$, cold carcass weight $(4.44 \mathrm{vs} .4 .29 \mathrm{~kg})$ and farm dressing percentage $(51.7 \mathrm{vs.} 50 \%$ ) of the conventionally raised kids were significantly higher than those of the organic kids. The shoulder (first category) (21.7 vs. $22.3 \%$ ) and long leg (32 vs. 32.9\%) percentages were lower in the conventional than in the organic kids. The percentage contribution of the intermuscular fat $(\mathbf{1 0 . 7 0} \mathrm{vs} . \mathbf{8 . 1 1 \%})$ to the shoulder weight was greater in the conventional kids, while the percentages of muscle $(59.7$ vs. $57.2 \%)$ and bone $(24.7 \mathrm{vs.} 22.8 \%)$ were higher in the organic kids. For the chemical composition, there were only differences between the two sexes in the percentage of fat (6.64 and $7.99 \%$ on dry matter, for male and female, respectively). For rheological variables, only differences were found in the water holding capacity (\% water expelled), the meat of the organic females had a higher value (17\%) than that of the conventional females (14\%). For the meat colour, the conventional male kids returned the highest values for $C^{*}$ and $H^{o}$ (14.32 and 64.34, respectively). Farms following conventional grazing-based management could easily switch to organic production. Most of the meat and carcass quality variables studied were very similar across the systems.
\end{abstract}

Key words: organic farm, conventional farm, grazing systems, livestock production system, gender

*Work financed from: Instituto Andaluz de Investigación and Formación Agraria, Pesquera, Alimentaria and de la Producción Ecológica of the Consejería de Agricultura and Pesca de la Junta de Andalucía, Spain, financial support via proposal No. 75 (Expdte. 92162/1). 
Goat farming in Spain is an alternative to mainstream meat production and provides employment for people living in rural areas. By grazing in marginal areas, goats also perform ecological and social functions (e.g., landscape maintenance, prevention of wildfires, etc.). In the European Union, Spain has the second highest goat head number (3.1 million) and Andalusia (in southern Spain) is the region with major census (FAO, 2017). With 531 organic goat farms in Spain, Andalusia has 68\% of the national total. Three hundred and seventy seven of these farms are dedicated to meat production, and 154 are dairy farms. Several countries in the Mediterranean Basin also have appreciable numbers of organic goat farms (Kyriazakis and Zervas, 2002), the results of which confirm the viability of the system.

Although most of the goats in Spain are dairy breeds, goat meat farming is also significant. The preferred goat carcass in Spain comes from suckling kids (animal only fed on milk and slaughtered at 8-10 kg live weight and aged 35-45 days) (Marichal et al., 2003). Consumption is twice as high in December as in any other month of the year (Alcalde et al., 2013).

It is essential that native breeds normally raised under grazing systems, such as Payoya goats (a dairy breed considered endangered by the Official Catalogue of Spanish Livestock Breeds) be preserved. Despite the social and environmental advantages offered by goat pastoral systems, they are likely to disappear if they are economically unviable (Castel et al., 2011). Recent reports (Gutiérrez-Peña et al., 2016; Mena et al., 2017) in which the productive and economic results of Payoya goat-raising systems are analysed conclude that although costs can be reduced through grazing, thus improving farm profitability, true economic viability demands society pay for the ecosystem services provided. These authors also propose taking actions designed to enhance the viability of farms, such as implementing strategies to improve the marketing of their animal products, e.g., through specific certification. Another possibility could be to transform mountain goat grazing systems into organic production systems (Mena et al., 2009). The possibility of such a transformation, however, requires that a farm's technical and economic viability as an organic operation be assessed. The quality of its product must also be examined to be sure that quality is maintained. A previous study on the possibility of switching conventional Payoya goat-raising to organic production (De la Vega et al., 2013) compared the fatty acid composition of kid meat. The results indicated that conventional farms could easily turn to organic production. By way of extension, the aim of the present work was to compare the carcass and meat quality of Payoya suckling goat kids (both sexes) raised under conventional and organic and grazing-based production systems.

\section{Material and methods}

\section{Study area, experimental farm goats and kids}

The kids used in this study were all of the Payoya breed and came from farms (belonging to the Payoya Breeders' Association and chosen in agreement with this association [Mena et al., 2009]) located in the Sierra Norte de Cádiz range of hills (Andalusia, Spain): 24 (12 males and 12 females) from an organic farm certified un- 
der Regulation EC 834/2007 (36 46 $\left.52^{\prime \prime} \mathrm{N}, 5^{\circ} 32^{\prime} 14^{\prime \prime} \mathrm{W}\right)$, and 24 (12 males and 12 females) from a conventional farm $\left(36^{\circ} 46^{\prime} 14^{\prime \prime} \mathrm{N}, 5^{\circ} 21^{\prime} 25^{\prime \prime} \mathrm{W}\right)$. Within each farm, dams and kids were selected randomly in the same season. All kids were kept in pens and had free access to dams at night, but not to feedstuff.

The dams in both experimental farms were raised under similar semi-extensive systems based on the grazing of natural pasture (De la Vega et al., 2013). Under these semi-extensive systems, bucks were maintained with the doe herd during the mating season (3 months on average and the male-to-female ratio was approximately 1 male per 20 females) for continuous breeding and the main kidding period was in autumn (unpublished data). In addition, both systems were characterized by low stocking density, few health problems, and grazing as an integral part of the animals' feeding. However, the conventionally raised animals were fed more concentrates; supplementary feed concentrate (with organically-grown constituents) was added at a flat rate of $1.0 \mathrm{~kg} \mathrm{head}^{-1} \mathrm{~d}^{-1}$ on the conventional farm, and at $0.5 \mathrm{~kg} \mathrm{head}^{-1} \mathrm{~d}^{-1}$ on the organic farm (De la Vega et al., 2013).

\section{Slaughter and carcass quality}

Goat kids after reaching the target commercial live weight were routinely kept overnight with their mothers in the conditions of each farm. The next day and before transport to the slaughterhouse, the farm live weight (FLW) was recorded. All goat kids were slaughtered at an average FLW of $8.40 \pm 0.06 \mathrm{~kg}$ and an average age of 33 days, after $16.33 \pm 0.12 \mathrm{~h}$ fasting with free access to water, in agreement with EU regulations (Regulation [EC] No 1099/2009). After slaughter, the carcasses were kept in a chilling room at $4^{\circ} \mathrm{C}$ for $24 \mathrm{~h}$ and then split down the dorsal midline. The left half of each carcass was removed according to the procedure of Colomer-Rocher et al. (1987) and transported under refrigeration to the laboratory.

Slaughter live weight (SLW, recorded immediately prior to slaughter), carcass weight and subcutaneous fatness scores were recorded, and the empty body weight (EBW), chilling losses and dressing percentage calculated. Hot carcass weight (HCW) and the weight of the non-carcass components (blood, skin, head, feet, heart, lungs and trachea, liver, spleen, thymus, full and empty gastrointestinal tract) were recorded after slaughter. The gastrointestinal content was determined as the difference between the full and empty gastrointestinal tract. The tail, kidneys, peri-renal and pelvic fat, and the testes were retained in-carcass. After chilling $\left(24 \mathrm{~h}\right.$ at $\left.4^{\circ} \mathrm{C}\right)$, the cold carcass weight $(\mathrm{CCW})$ was recorded and the EBW calculated by subtracting the weight of the gastrointestinal contents from the SLW. Each carcass was then assessed for subcutaneous fatness (scale from $1=$ low to $5=$ very high) using the scoring system of Colomer-Rocher et al. (1987). Carcass dressing percentages and chilling losses were calculated as follows: farm dressing percentage (FDP $)=100 \times(\mathrm{HCW} /$ FLW); slaughter dressing percentage $(\mathrm{SDP})=100 \times(\mathrm{HCW} / \mathrm{SLW})$; commercial dressing percentage $(\mathrm{CDP})=100 \times(\mathrm{CCW} / \mathrm{SLW})$; real dressing percentage $(\mathrm{RDP})=100 \times$ $(\mathrm{HCW} / \mathrm{EBW})$; biological dressing percentage $(\mathrm{BDP})=100 \times(\mathrm{CCW} / \mathrm{EBW})$; and chilling losses $(\mathrm{CH})=(\mathrm{HCW}-\mathrm{CCW}) \times 100 / \mathrm{HCW}$.

Carcass linear measurements (in $\mathrm{cm}$ ) were made based on standard protocols (Palsson and Verges, 1952); these included internal carcass length (L), exter- 
nal carcass length $(\mathrm{K})$, leg length $(\mathrm{F})$, buttock width $(\mathrm{G})$, buttock perimeter $(\mathrm{BG})$, chest depth (Th), thorax width (Wr), and thoracic perimeter (PT). The following indices were then calculated from these measurements: 1) L/G; 2) Th/G; 3) Th/K; 4) carcass compactness i.e., CCW/L; 5) leg compactness, i.e., leg weight/F; 6) chest roundness i.e., Wr/Th; 7) the buttock/leg index, i.e., G/F and 8) hot carcass weight/L index.

After chilling, the half-carcass was weighed and physically dissected into five prime cuts (shoulder, flank, neck, ribs and long leg) according to Colomer-Rocher et al. (1987). These were weighed and grouped into three categories: Extra (long leg and ribs), First (shoulder) and Second (neck and flank). Minor cuts (tail, testes, kidney, kidney fat and pelvic fat) were removed before jointing and weighed. The shoulder was vacuum packed and frozen at $-20^{\circ} \mathrm{C}$ until analysis (approximately 2-3 months). The shoulder, after thawing under chilling conditions $\left(4^{\circ} \mathrm{C}\right)$ for 24 $\mathrm{h}$, was weighed and separated into dissectible fat (subcutaneous + intermuscular), muscle, bone and the remainder (major blood vessels, ligaments, tendons and thick connective tissue sheets associated with some muscles) in a dissection room under controlled environment with a temperature maintained below $15^{\circ} \mathrm{C}$. Each component of tissue composition was calculated as percentage on shoulder weight. The muscle/bone and muscle/fat indices were then calculated, as were the dissection losses (calculated as the shoulder weight difference before dissection and the sum of the weights of all constituents after dissection and expressed as percentage on weight before dissection), and freezing losses (calculated as the shoulder weight difference before and after freezing and expressed as percentage on weight before freezing).

\section{Meat sampling and analysis}

Meat colour and $\mathrm{pH}$ were evaluated $24 \mathrm{~h}$ after slaughter. The colour was measured in the longissimus muscle (4th/5th lumbar vertebra), directly on the muscle surface after its removal with a scalpel and freeing from connective tissue. All meat colour variables - lightness $\left(L^{*}\right)$, redness $\left(a^{*}\right)$, yellowness $\left(b^{*}\right)$ and the colorimetric indices of chroma $\left(C^{*}\right)$ and hue angle $\left(H^{\sigma}\right)$ - were assessed according to the CIELAB colour system (CIE, 1986) using a portable chromameter (Minolta CM-2002) (which provides the mean of three measurements). The $\mathrm{pH}$ was measured using a penetrating combined glass electrode with a Crison $25 \mathrm{pH}$ meter at the same site as the meat colour was examined.

After chilling the ribs for $24 \mathrm{~h}$, the longissimus muscle was dissected. Subsamples of the muscle were vacuum packed and frozen at $-20^{\circ} \mathrm{C}$. Before analysis, they were thawed at $4^{\circ} \mathrm{C}$ for $24 \mathrm{~h}$. Cooking losses were assessed in meat samples of similar shape; these were individually weighed and vacuum packed in plastic bags and left in a water bath at $75^{\circ} \mathrm{C}$ for $30 \mathrm{~min}$. The cooked samples were then cooled at room temperature, taken from the bags, dried with filter paper, and reweighed. Cooking loss was expressed as the percentage weight loss (with respect to the initial weight). Samples of the cooked meat were then used to determine objective tenderness. The Warner-Bratzler shear force (WBSF) was measured in sub-samples (at least 3 ) of $1 \mathrm{~cm}^{2}$ cross section and with fibres perpendicular to the 
direction of a blade attached to a Stevens QTS 25 apparatus. The results were expressed in $\mathrm{kg} / \mathrm{cm}^{2}$.

The water holding capacity (WHC) (uncooked samples) was determined according to Alcalde et al. (2017) (performed in duplicate). Samples of raw meat were minced into small pieces and approximately $5.0 \mathrm{~g}$ was weighed, then covered with two filter papers (Albet 238, $12.5 \mathrm{~cm}$ diameter) and two thin plates of glass material and pressed with a load of $2.25 \mathrm{~kg}$ for $5 \mathrm{~min}$. After accurately removing the compressed meat sample from the filter paper, the sample was rapidly weighed. Water holding capacity was expressed as the percentage of expelled juice after compression.

Haem pigment content was examined according to Hornsey (1956) (performed in duplicate) and expressed as myoglobin $\mathrm{mg} \mathrm{g}^{-1}$ fresh muscle. The muscle samples minced $(5.0 \mathrm{~g})$ were extracted with an acetone and $\mathrm{HCl}$ solution, stored sealed for $24 \mathrm{~h}$ in the dark at room temperature, and then filtered (Whatman $\mathrm{N}^{\circ} 1$ ). The absorbance was measured using a spectrophotometer at $510 \mathrm{~nm}$ wavelength. Haem pigment content was estimated by multiplying the absorbance by factor 8.816 .

Once thawed, the shoulder was dissected to obtain the triceps brachii muscle with no attached intermuscular fat or tendons, and its proximate composition (moisture, ash, crude protein and fat) determined according to AOAC procedures (1984).

\section{Statistical analysis}

Differences in the studied variables were analysed by ANOVA using the general linear model (GLM), contemplating the production system and gender as fixed effects. Pairwise comparisons of means were performed where appropriate using Tukey's honest significant difference test. Significance was set at $\mathrm{P} \leq 0.05$. All calculations were made using SPSS software for Windows (version 24.0; IBM Corp., Armonk, New York, USA).

\section{Results}

\section{Carcass quality}

The morphology of the carcass and some of the dressing percentages differed between production system and gender (Tables 1 and 2). However, the interaction of production system $\times$ gender had no influence on these variables $(\mathrm{P}>0.05)$. The conventional kids had higher SLW, HCW, CCW $(\mathrm{P} \leq 0.05)$, EBW and FDP $(\mathrm{P}<0.01)$ values than the organic kids, while the fasting losses were higher for the organic kids $(\mathrm{P}<0.001)$. The values for $\mathrm{HCW}, \mathrm{CCW}$ and all dressing percentages were higher in the males than in the females $(\mathrm{P} \leq 0.05)$. Regarding the linear measurements of the carcass and index (Table 2), the conventional kids had higher values for $\mathrm{K}$ $(\mathrm{P}<0.01)$, Wr and $\mathrm{Wr} / \mathrm{Th}(\mathrm{P}<0.001)$, while the organic kids had higher $\mathrm{Th}(\mathrm{P} \leq 0.05)$, $\mathrm{Th} / \mathrm{K}(\mathrm{P}<0.001)$ and $\mathrm{Th} / \mathrm{G}$ values $(\mathrm{P}<0.01)$. The values of $\mathrm{K}(\mathrm{P}<0.01)$, Th and Leg Weight $/ F$ were higher $(\mathrm{P} \leq 0.05)$ for the male than for the female kids. 


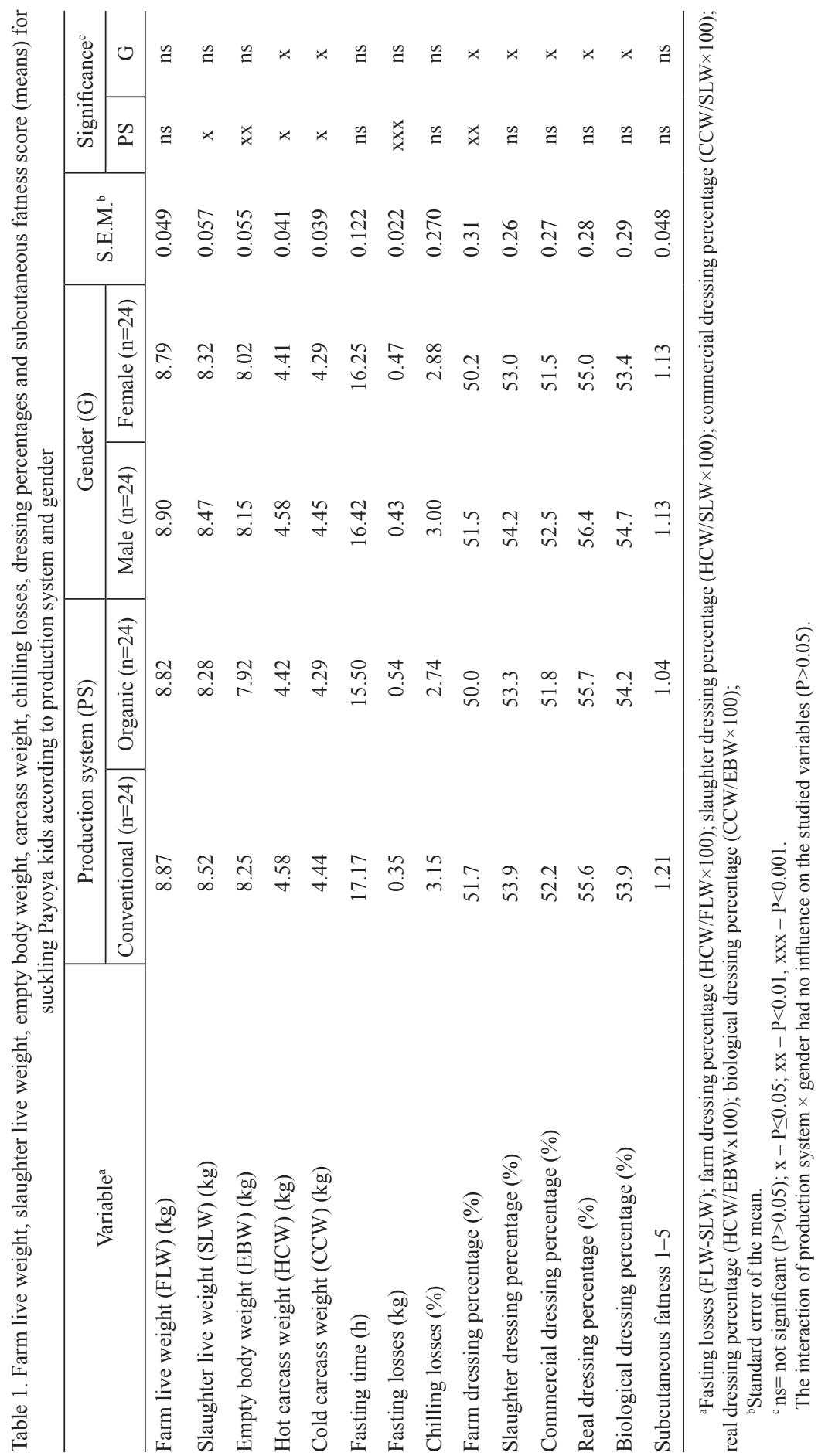




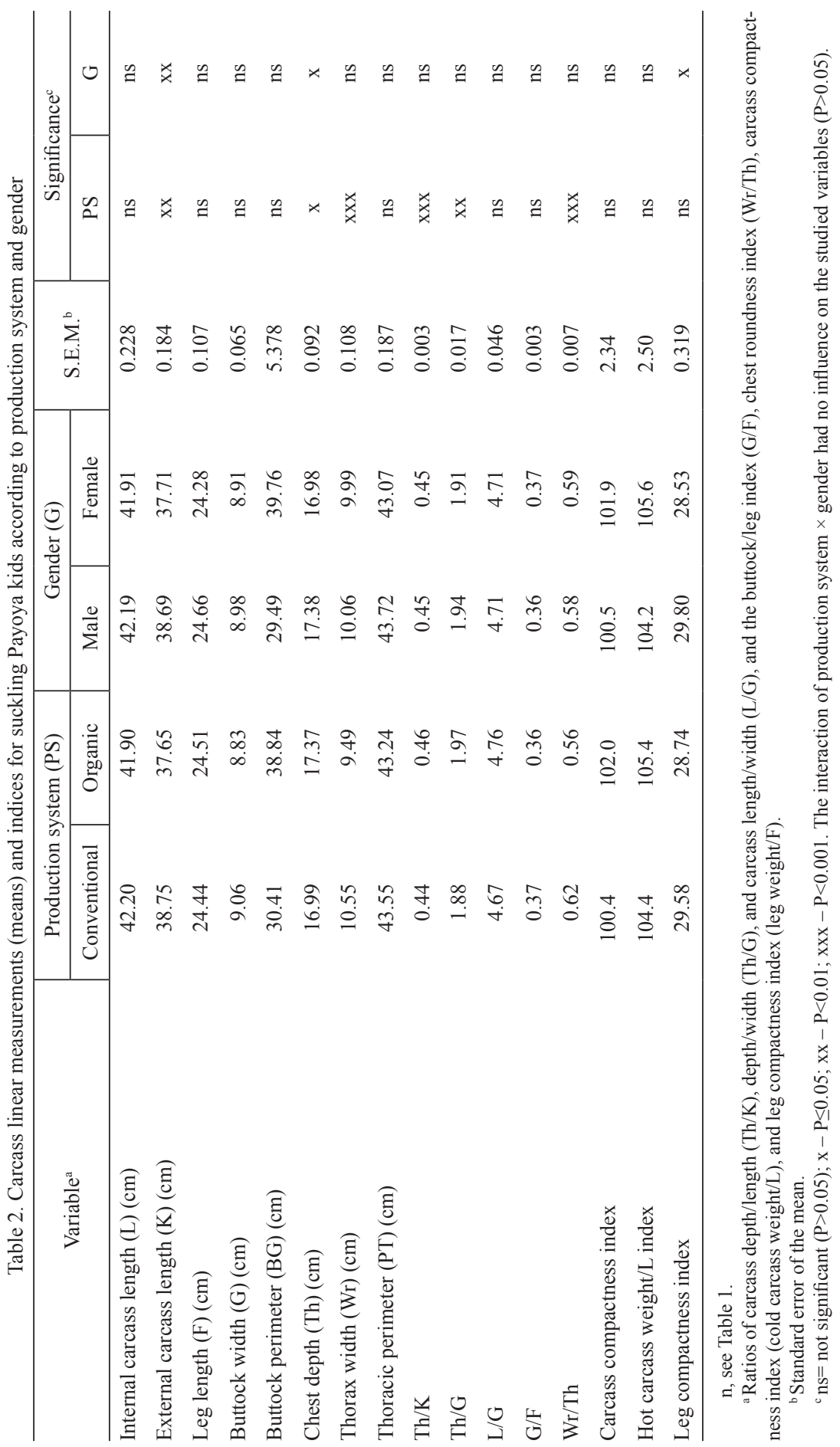




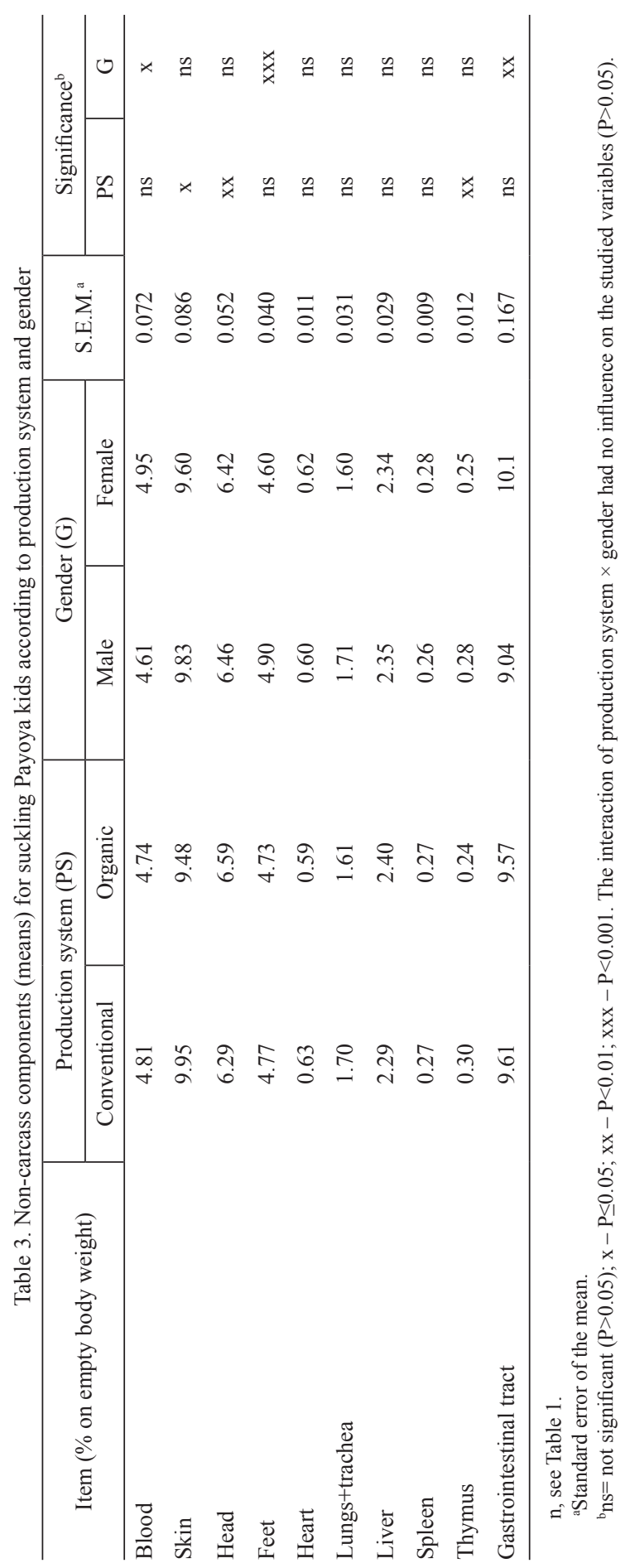




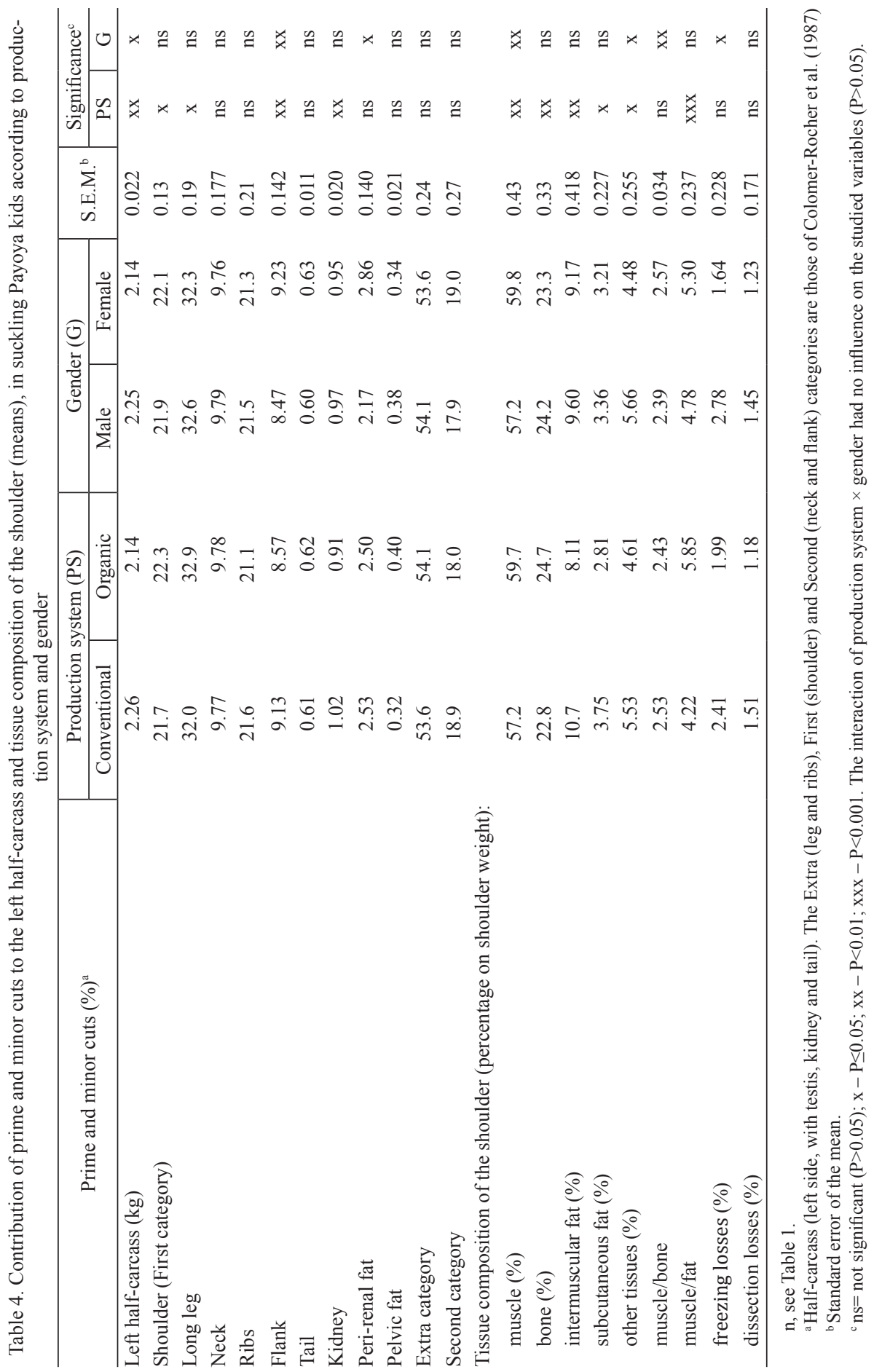


Differences were seen between the studied production systems and between the sexes for some of the offal components examined (Table 3). However, the interaction of production system $\times$ gender had no influence on these variables $(\mathrm{P}>0.05)$. The percentage contributions to EBW of the skin $(\mathrm{P} \leq 0.05)$ and thymus $(\mathrm{P}<0.01)$ were higher in the conventional kids, while the percentage contribution of the head was greater $(\mathrm{P}<0.01)$ in the organic kids. In addition, the percentage contribution of the feet to EBW was higher $(\mathrm{P}<0.001)$ in the males than in the females, whereas those of the blood $(\mathrm{P} \leq 0.05)$ and gastrointestinal tract $(\mathrm{P}<0.01)$ were lower.

The percentage contributions of prime and minor cuts to the left half-carcass weight were affected by both production system and gender (Table 4), but not by their interaction $(\mathrm{P}>0.05)$. The left half-carcass weights, and the percentage contributions of the flank and kidney to it, were greater in the conventional kids than the organic kids $(\mathrm{P}<0.01)$ while the percentage contributions of the shoulder and leg cuts were lower. The left half-carcass weight of the males was greater $(P \leq 0.05)$ than that of the females, while the percentage contributions of the flank $(\mathrm{P}<0.01)$ and perirenal fat $(\mathrm{P} \leq 0.05)$ of the males to that weight were lower (Table 4).

The production system and sex of the present kids each had an effect on the composition of the shoulder tissue (Table 4), although the interaction of production system $\times$ sex had no influence. The percentage contribution of the intermuscular fat $(\mathrm{P}<0.01)$, subcutaneous fat $(\mathrm{P} \leq 0.05)$ and other tissues $(\mathrm{P} \leq 0.05)$ to the shoulder weight was greater in the conventional kids, while those of muscle and bone $(\mathrm{P}<0.01)$ and the muscle/fat ratio $(\mathrm{P}<0.001)$ were lower. Other tissue contributions and freezing losses were greater $(\mathrm{P} \leq 0.05)$ in the male than in the female kids, while the percentage contribution of the muscle to the shoulder weight, and the muscle/ bone ratio, were lower $(\mathrm{P}<0.01)$.

\section{Meat quality}

The production system had no effect on the chemical composition of the triceps brachii muscle or any rheological variable of the longissimus dorsi muscle (Table 5). The WHC for the longissimus muscle was, however, influenced by production system, gender and the interaction of production system $\times$ gender $(\mathrm{P}<0.001)$ : the meat of the organic females had a higher value $(17 \pm 1 \%)$ than that of the conventional females $(14 \pm 1 \%)$. No differences were seen between the organic and conventional male kids (data not shown). Gender only affected the percentage of intramuscular fat in the triceps brachii muscle $(\mathrm{P}<0.01)$, the female kids having higher values (Table 5).

Meat $\mathrm{pH}$ was not affected by production system or gender, or their interaction (Table 6). With respect to meat colour, differences were seen between the production system for $\mathrm{L}^{*}$ (Table 6$)$, with higher values returned by the organic kids $(\mathrm{P} \leq 0.05)$. The $\mathrm{a}^{*}$ value was not influenced by production system and $\mathrm{C}^{*}$ was not influenced by gender. The interaction of production system $\times$ gender had influence on $\mathrm{a}^{*}(\mathrm{P}<0.01)$, $\mathrm{b}^{*}(\mathrm{P}<0.001), \mathrm{C}^{*}(\mathrm{P}<0.001)$ and $H^{o}(\mathrm{P}<0.001)$ (Table 6), the conventional male kids returning the highest values for $b^{*}(12.81), C^{*}(14.32)$ and $H^{o}(64.34)$ and lowest values for $a^{*}(6.09)$. 


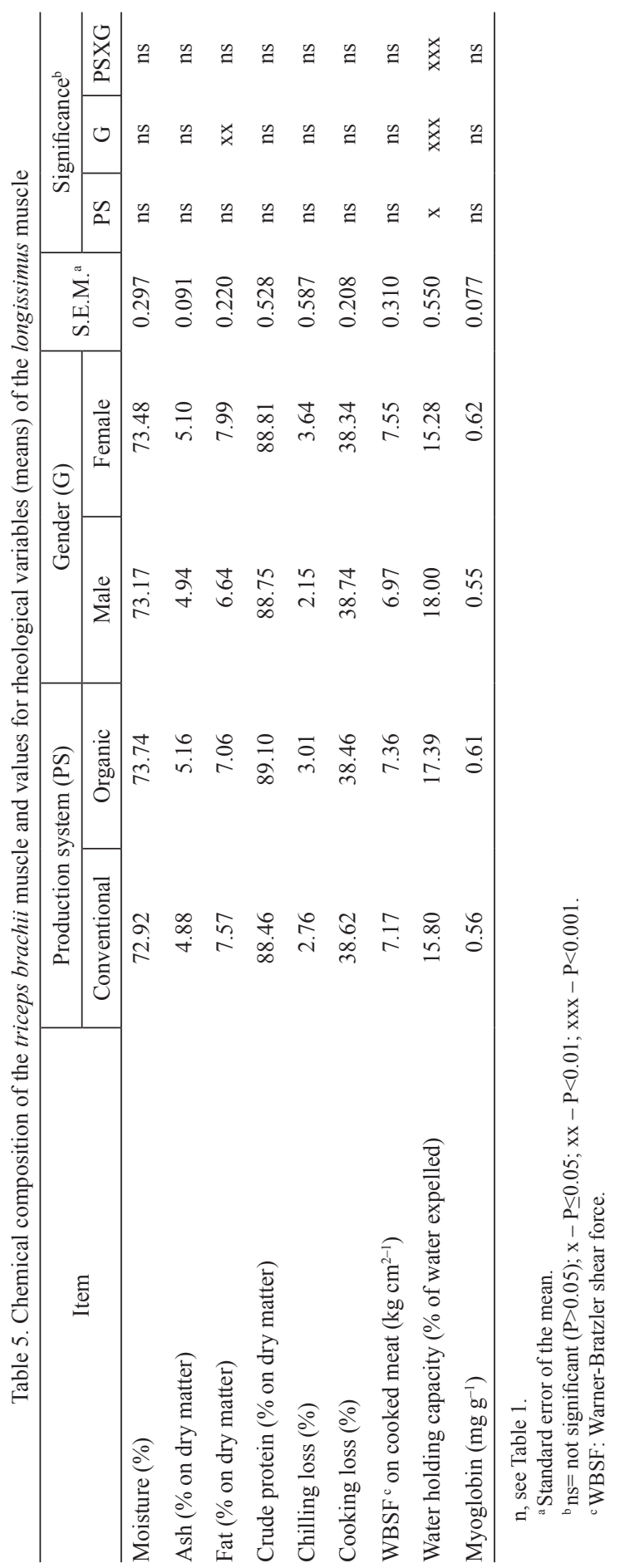


Table 6. $\mathrm{pH}$ and colorimetric variables (means) at $24 \mathrm{~h}$ post-slaughter for the longissimus muscle

\begin{tabular}{l|cc|c|c|c|c|c|c}
\hline \multirow{2}{*}{ Item $^{\mathrm{a}}$} & \multicolumn{2}{|c|}{ Production system (PS) } & \multicolumn{2}{|c|}{ Gender $(\mathrm{G})$} & \multirow{3}{*}{ S.E.M. $^{\mathrm{b}}$} & \multicolumn{3}{|c}{ Significance $^{\mathrm{c}}$} \\
\cline { 2 - 3 } & Conventional & Organic & Male & Female & & $\mathrm{PS}$ & $\mathrm{G}$ & $\mathrm{PSxG}$ \\
\hline $\mathrm{pH}$ & 6.02 & 6.07 & 6.03 & 6.06 & 0.031 & $\mathrm{~ns}$ & $\mathrm{~ns}$ & $\mathrm{~ns}$ \\
$\mathrm{~L}^{*}$ & 44.54 & 46.64 & 45.42 & 45.76 & 0.508 & $\mathrm{x}$ & $\mathrm{ns}$ & $\mathrm{ns}$ \\
$\mathrm{a}^{*}$ & 7.80 & 8.65 & 7.28 & 9.17 & 0.292 & $\mathrm{~ns}$ & $\mathrm{xxx}$ & $\mathrm{xx}$ \\
$\mathrm{b}^{*}$ & 9.41 & 6.15 & 9.14 & 6.42 & 0.529 & $\mathrm{xxx}$ & $\mathrm{xxx}$ & $\mathrm{xxx}$ \\
$C^{*}$ & 12.88 & 10.78 & 12.27 & 11.40 & 0.337 & $\mathrm{xxx}$ & $\mathrm{ns}$ & $\mathrm{xxx}$ \\
$H^{\text {o }}$ & 47.91 & 33.39 & 47.84 & 33.47 & 2.433 & $\mathrm{xxx}$ & $\mathrm{xxx}$ & $\mathrm{xxx}$ \\
\hline
\end{tabular}

n, see Table 1.

${ }^{a} L^{*}$ : luminosity; $a^{*}$ : red index; $b^{*}$ : yellowness index; $C^{*}$ or saturation $=\left(a^{* 2}+b^{* 2}\right)^{0.5} ; H^{o}=\operatorname{Tan}^{-1}\left(b^{*} / a^{*}\right)$ expressed in degrees (CIE, 1986).

${ }^{\mathrm{b}}$ Standard error of the mean.

${ }^{\mathrm{c}} \mathrm{ns}=$ not significant $(\mathrm{P}>0.05) ; \mathrm{x}-\mathrm{P} \leq 0.05 ; \mathrm{xx}-\mathrm{P}<0.01 ; \mathrm{xxx}-\mathrm{P}<0.001$.

\section{Discussion}

\section{Carcass quality}

The dams were raised under similar semi-extensive conditions based on the grazing of natural pasture, but the supplementary feed provided to the dams on the organic farm was less copious than that provided on the conventional farm (see De la Vega et al., 2013). However, the kids were fed exclusively on their mothers' milk, and although in the present work the composition of the milk was not examined, the provision of concentrate to the dams, as the only feeding factor that could have influenced the values record, was insufficient to modify most carcass and meat quality parameters.

Farm live weight, carcass weights and dressing percentages results of Payoya kids were in agreement with previous studies and in accordance with the preferred goat carcass in the Mediterranean countries (Marichal et al., 2003; Peña et al., 2007; Zurita Herrera et al., 2011). The scarce significant differences between the production systems in terms of SLW, EBW, HCW, CCW and farm dressing percentage, while the FLW was not different, could be due to greater pre-slaughter fasting losses in the organic kids, despite having the same fasting time (see Table 1). In support of this hypothesis, the gastrointestinal tract weight was the same in kids raised under both systems. Although stress response variables were not measured and the management of the animals until slaughter in both farms was similar, the greater fasting losses in the organic kids could be attributed to stress in pre- and post-transport operations, likely associated with increased muscle activity and liver glycogen and body fat mobilization (Alcalde et al., 2017) and also to the evacuation of the gastrointestinal tract. In agreement with the stress hypothesis, the organic kids showed lower percentages (on shoulder weight) of intermuscular and subcutaneous fat. Similarly, Morbidini et al. (2001), who worked with the Italian Merino sheep breed (slaugh- 
tered at 75 days), attributed the lower warm dressing percentages to early weaning and transportation stress. The different values for HCW, CCW and all dressing percentages between males and females might be explained by the greater contribution of the gastrointestinal tract weight to the EBW in the females (10\% vs. $9 \%$ in males). In contrast, Peña et al. (2007) reported no differences between the sexes for any of these variables in Florida breed kids of similar SLW. Similarly, Zurita Herrera et al. (2011) found no differences between the sexes for HCW, CCW, CDP and RDP in Murciano-Granadina breed kids of slightly lower SLW.

Zurita Herrera et al. (2011) reported lower F, L and G values for kids raised in an intensive system compared to those raised in other systems in which they accompanied their mothers during grazing - and therefore expended more energy. The values of the carcass linear measurements and indices for all systems were, however, generally similar to those recorded in the present study. The small differences observed between the systems studied in the present work are hard to explain since all the kids were confined to a pen and did not accompany their mothers during grazing - their physical activity was therefore similar. However, the higher values observed in some linear measurements ( $\mathrm{K}$ and $\mathrm{Wr} / \mathrm{Th}$ ) of the conventionally produced carcasses could be explained by the higher SLW and EBW found in these goat kids. Cutrignelli et al. (2007), who investigated the influence of conventional and organic systems on the performance of Cilentana breed kids, found no differences between their live and carcass variables.

Zurita Herrera et al. (2011) reported no differences in most of offal components examined when comparing Murciano-Granadina kids of similar weight reared in intensive, semi-intensive and extensive systems. However, Cutrignelli et al. (2007), who compared the same management systems (conventional vs. organic), found differences in the slaughter measurements (i.e., empty digestive tract, skin, liver + spleen, and kidney + bladder). Nonetheless, the values reported by these other authors were very similar to those recorded in the present work. With respect to sex, other authors (Johnson et al., 1995) reported that female goats (slaughter weight 20 $+3.4 \mathrm{~kg}$ ) had lower percentage contributions of the feet to the half-carcass weight. In a similar study involving Florida breed kids with an SLW of 7-8 kg, Peña et al. (2007) found no effect of gender on any non-carcass component percentages.

The percentage contributions of prime and minor cuts to the left half-carcass weight were affected by both production system and gender. However, these small differences are biologically irrelevant. The values for these variables were higher than those reported by other authors (Zurita Herrera et al., 2011) for kids of similar weight but different breed - Murciano-Granadina - which might explain the discrepancy. Similarly, Peña et al. (2007) found no differences between the sexes with respect to the percentage contribution of prime cuts in Florida breed kids weighing $7-8 \mathrm{~kg}$ at slaughter.

The differences observed between systems on the composition of the shoulder tissue might be explained by stress in pre- and post-transport operations and also by the lower energy/protein levels of the diet consumed by the organic kids' mothers they were allowed $0.5 \mathrm{~kg}$ less concentrate per day, which might have translated into smaller amounts of milk (or milk of lower quality) being consumed by their kids. 
Atti et al. (2004) concluded that kids fed a medium crude protein diet (130 g kg $\mathrm{DM}^{-1}$ ) had relatively more muscle and less adipose tissue than those on a high protein diet. Liméa et al. (2012), who examined the effects of a concentrate-based diet on the carcass fat of Creole breed goats (slaughtered at a body weight of 22-24 kg), reported them to have greater cold carcass, omental, peri-renal and intermuscular adipose tissue weights than goats fed tropical green forage. However, Cutrignelli et al. (2007) reported the body composition not to be influenced by the production system method (conventional or organic). With regard to the gender effect, Todaro et al. (2004) reported similar results to those obtained in the present work for other tissue and muscle weight contributions to the pelvic limb in Nebrodi breed kids that were slightly heavier at slaughter. In contrast, Peña et al. (2007) reported other tissues to make a greater contribution in female Florida breed kids of similar slaughter weight, but saw no sex differences in terms of the percentage contribution of muscle to the shoulder (58.1 and 57.6\% for males and females, very similar to the results obtained in the present work despite the differences in breed). Zurita Herrera et al. (2011), who worked with Murciano-Granadina kids, raised under 3 different management systems (extensive, semi-intensive and intensive) found no differences in the contribution of the intermuscular and subcutaneous fat to the shoulder weight, although their values were lower than those recorded in the present study.

\section{Meat quality}

Payoya kid meat was very lean, with little intramuscular fat and ash content, and rich in water, typical of meat from suckling kids; similar values to those found by Bañón et al. (2006), in Murciano-Granadina male goat kids, also fed with natural milk by their dams and slaughtered at 35 days of age and weighing $7.6 \mathrm{~kg}$. Cooking loss results and Warner Bratzler shear force values of Payoya kids were in accordance with previous studies (Ekiz et al., 2010). There was no effect of the production system on the chemical composition and rheological parameters, except for WHC of longissimus dorsi muscle, for which there was interaction between the production system and gender. In a previous study reported by Cutrignelli et al. (2007), the meat WHC was unaffected by the production system. In our work, a high WHC has been found (typical of meat from very young animals) which was even higher than the value found, under similar conditions, in Murcian-Granadina kids (Bañon et al., 2006). Gender only affected the percentage of intramuscular fat of triceps brachii muscle, higher for females. However, Todaro et al. (2004) observed no differences between the sexes with respect to pelvic limb meat chemical composition. In our study we found no effect on the $\mathrm{pH}$ of the production system. In contrast, Caputi Jambrenghi et al. (2007) reported production system-related differences in the $\mathrm{pH}$ of the longissimus lumborum muscle at 45 min post-slaughter, with intensive production animals having a higher $\mathrm{pH}$ than those that accompanied their mothers during grazing.

Compared to the results of our study, Bañón et al. (2006) in goat kids slaughtered with a similar weight found a higher myoglobin content $(1.26 \mathrm{mg} / \mathrm{g})$ and a lower $H^{o}$ (19.48); however, the values of $L^{*}$ and $C^{*}$ were very similar. Also in our study, the colour parameters at $24 \mathrm{~h}$ were very similar to those found by Ekiz et al. (2010) 
in Turkish Saanen, Gokceada and Maltese suckling kids, although the former were slaughtered at a higher weight. Meat colour influences consumer purchasing choices (Zervas and Tsiplakou, 2011), and it is well known that an animal's diet can affect the colour of its meat (Priolo et al., 2001). Indeed, $L^{*}$ and $b^{*}$ have been closely linked to the quantity and quality of the intramuscular fat (De Palo et al., 2012; Mancini and Hunt, 2005), and consequently the fatty acid composition and the degree of lipid oxidation correlate strongly with meat colour (Emami et al., 2015; Luciano et al., 2009). The production system-related differences in muscle fatty acid composition reported in a previous study (De la Vega et al., 2013) might help explain the present differences in meat colour. However, Emami et al. (2015) affirm that the $H^{o}$, which is a function of $a^{*}$ and $b^{*}$, gives a more realistic idea of the degree of meat browning than single colour coordinates. In the present work, the higher $H^{o}$ values of the conventional male kid meat confirm it to be of a somewhat lighter red colour. Regarding meat colour parameters and stress, Kannan et al. (2003) suggested that young animals might be more susceptible to changes leading to lower meat quality due to transport stress, given that transport did not modify colour attributes of longissimus dorsi in large-size goat kids (54 kg LW), whereas in younger animals $(22 \mathrm{~kg}$ $\mathrm{LW})$ both $a^{*}$ and $C^{*}$ decreased. According to this, in our study the lowest value of $\mathrm{C}^{*}$ obtained in the organic kids could be attributed to stress in pre- and post-transport operations.

The present results suggest that conventional grazing-based management farms could be easily transformed into organic farms. Most of the meat and carcass quality variables studied were very similar across the systems. However, there have been differences in some variables, mainly in the conventional kids were higher some weights (slaughter live, empty body and carcass), the farm dressing percentage, the percentages of the intermuscular and subcutaneous fat of the shoulder and certain meat colour variables $\left(C^{*}\right.$ and $\left.H^{\circ}\right)$; while in the organic kids were higher the weight of the shoulder, the long leg, the percentages of muscle and bone of the shoulder, the water holding capacity and the luminosity $\left(L^{*}\right)$. Gender, irrespective of the production system, mostly affected the carcass weight, the dressing percentages, the muscle/bone, water holding capacity and certain meat colour variables $\left(C^{*}\right.$ and $\left.H^{\circ}\right)$, which were higher in the male kids.

\section{Acknowledgments}

The authors are grateful to the Instituto Andaluz de Investigación and Formación Agraria, Pesquera, Alimentaria and de la Producción Ecológica of the Consejería de Agricultura and Pesca de la Junta de Andalucía for financial support via proposal No. 75 (Expdte. 92162/1). The authors are also grateful to goat farmers Daniela Hinojo Antille and Manuel Sánchez for their collaboration in this work.

\section{References}

A lcalde M.J., Ripoll G., Panea B. (2013). Consumer attitudes towards meat consumption in Spain with special reference to quality marks and kid meat. In: Consumer attitudes to food quality products, EAAP Publication, 133: 97-107. 
A lcalde M.J., S uárez M.D., Rodero E., Álvarez R., Sáez M.I., Martínez T.F. (2017). Effects of farm management practices and transport duration on stress response and meat quality traits of suckling goat kids. Animal, 11: 1626-1635.

AOAC (1984). Official Methods of Analysis (14th ed.). Arlington, VA: Association of Official Analytical Chemists.

A t t i N., R o u is s i H., M a h o u a c h i M. (2004). The effect of dietary crude protein level on growth, carcass and meat composition of male goat kids in Tunisia. Small Rumin. Res., 54: 89-97.

B a ñón S., Vil a R., Pri c e A., F errandini E., Garrido M.D. (2006). Effects of goat milk or milk replacer diet on meat quality and fat composition of suckling goat kids. Meat Sci., 72: 216-221.

Caputi Jambrenghi A., Colonna M.A., Giannico F., Cappiello G., Vonghia G. (2007). Effect of goat production systems on meat quality and Conjugated Linoleic Acid (CLA) content in suckling kids. Ital. J. Anim. Sci., 6: 612-614.

Castel J.M., Mena Y., Ru iz F.A., C a muñez-Ruiz J., Sánchez-Rodrígue z M. (2011). Changes occurring in dairy goat production systems in less favoured areas of Spain. Small Rumin. Res., 96: 83-92.

CIE (1986). Comisión Internationale de l'Eclairage. Colorimetry (2nd ed.). Vienna, Publication 15.2.

Colomer-Rocher F., Morand-Fehr P., Kirton H. (1987). Standard methods and procedures for goat carcass evaluation, jointing and tissue separation. Livest. Prod. Sci., 17: 149-159.

Cutrignelli M.I., Tudisco R., Bovera F., Piccolo G., D'Urso S., Infascelli F. (2007). Influence of goat livestock systems on the performance of Cilentana kids. Options Méditerran. Series A, 74: 107-112.

De La Vega F., Guzmán J.L., De lgado-Pertíñez M., Z arazaga L.A., Argüello A. (2013). Fatty acid composition of muscle and internal fat depots of organic and conventional Payoya goat kids. Span. J. Agric. Res., 11: 759-769.

De Palo P., Maggiolino A., Centoducati P., Tateo A. (2012). Colour changes in meat of foals as affected by slaughtering age and post-thawing time. Asian-Australas. J. Anim. Sci., 25: $1775-1779$.

Ekiz B., Ozcan M., Yilmaz A., Tölü C., S a vas T. (2010). Carcass measurements and meat quality characteristics of dairy suckling kids compared to an indigenous genotype. Meat Sci., 85: 245-249.

Emami A., Fathi Nasri M.H., Ganjkhanlou M., Zali A., Rashidi L. (2015). Effects of dietary pomegranate seed pulp on oxidative stability of kid meat. Meat Sci., 104: 14-19.

FAO (2017). FAOSTAT Online Database (available at http://faostat.fao.org/, accessed March 2019).

Gutiérrez-Peña R., Mena Y., Ruiz F.A., De lga do - Pertíñ z M. (2016). Strengths and weaknesses of traditional feeding management of dairy goat farms in mountain areas. Agr. Sustain. Food Syst., 40: 736-756.

H o r n s e y H.C. (1956). The colour of cooked cured pork. 1. Estimation of the nitric oxide haem pigments. J. Sci. Food Agric., 7: 534-540.

J o h n s on D.D., M c G ow an C.H., N u r s e G., A n ou s M.R. (1995). Breed type and sex effects on carcass traits, composition and tenderness of young goats. Small Rumin. Res., 17: 57-63.

K a n n a n G., K o u a k o u B., Terrill T.H., G e l a y e S. (2003). Endocrine, blood metabolite, and meat quality changes in goats as influenced by short-term, preslaughter stress. J. Anim. Sci., 81: 1499-1507.

K y r i a za k is I., Z ervas G. (2002). Organic meat and milk from ruminants. In: EAAP publications, p. 106.

Liméa L., A lexandre G., B erthelot V. (2012). Fatty acid composition of muscle and adipose tissues of indigenous Caribbean goats under varying nutritional densities. J. Anim. Sci., 90: $605-615$.

Luciano G., Monah an F.J., Vasta V., Pennis i P., B ella M., Priolo A. (2009). Lipid and colour stability of meat from lambs fed fresh herbage or concentrate. Meat Sci., 82: 193-199.

Man c in i R.A., Hu n t M.C. (2005). Current research in meat colour. Meat Sci., 71: 100-121.

Marichal A., Castro N., Capote J., Z a morano M.J., A rgüello A. (2003). Effects of live weight at slaughter $(6,10$ and $25 \mathrm{~kg})$ on kid carcass and meat quality. Livest. Prod. Sci., 83: 247-256.

M e n a Y., N a he d J., R u iz F.A., C a s t e 1 J.M., L i g e r o M. (2009). Proximity to the organic model of dairy goat systems in the Andalusian mountains (Spain). Trop. Subtrop. Agroecosyt., 11: 69-73. 
Mena Y., Gutiérrez-P eña R., Rui z F.A., De lga do-Pertíñez M. (2017). Can dairy goat farms in mountain areas reach a satisfactory level of profitability without intensification? A case study in Andalusia (Spain). Agr. Sustain. Food Syst., 41: 614-634.

Morbidini L., Sarti D.M., Pollid ori P., Valig i A. (2001). Carcass, meat and fat in Italian Merino derived lambs obtained with "organic" farming systems. Options Méditerran. Series A, 46: 29-33.

Pals s on H., Verges J. (1952). Effects of the plane of nutrition on growth and development of carcass quality in lambs. J. Agric. Sci., 42: 1-12.

P eña F., P ere a J., García A., A c ero R. (2007). Effects of weight at slaughter and sex on the carcass characteristics of Florida suckling kids. Meat Sci., 75: 543-550.

Priolo A., Micol D., Agabriel J. (2001). Effects of grass feeding systems on ruminant meat colour and flavour. A review. Anim. Res., 50: 185-200.

Regulation (EC) No 834/2007 of 28 June 2007 on organic production and labelling of organic products and repealing Regulation (EEC) No 2092/91. DO L 189, 20-7-2007.

Regulation (EC) No 1099/2009 of 24 September 2009 on the protection of animals at the time of killing. D.O.U.E. L 303:1-30.

Z ervas G., Ts i pla k o u E. (2011). The effect of feeding systems on the characteristics of products from small ruminants. Small Rumin. Res., 101: 140-149.

Zurita Herrera P., Delgado Bermejo J.V., Argüello Henríquez A., Camacho Val1 ej o M.E., G e r m a n o C o s t a R. (2011). Effects of extensive system versus semi-intensive and intensive systems on growth and carcass quality of dairy kids. R. Bras. Zootec., 40: 2613-2620.

Received: 3 I 2019

Accepted: 8 VII 2019 